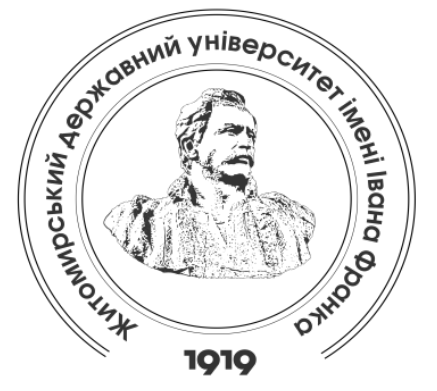

Zhytomyr Ivan Franko State University Journal. Philosophical Sciences. Vol. 1(85)

Вісник Житомирського державного університету імені Івана Франка. Фімософські науки. Вип. 1(85) ISSN: $2663-7650$

\title{
DOI 10.35433/PhilosophicalSciences.1(85).2019.25-35 \\ INFORMATIONAL VIOLENCE IN THE SYMBOLIC EXCHANGE AND MODERN MEDIAREALITY: THE MODUS DIMENSION
}

\section{M. Slyusar *}

The article touches upon the media violence as a component of social violence. When classifying violence by subject and orientation (self-directed, interpersonal and collective) we emphasize the latter, since it is expressed in social-political, social-economic and social-cultural forms and is a component of its realization. The dissemination of excessive or false information is part of its implementation. This is due to the fact that its implementation requires the creation of a sociocultural product, which is a specially selected video series of news, a special procedure and form of presenting these news (violation of the principles of objectivity, coverage of positions of only one side of the conflict, appeal to primitive desires in television programs), aggressive advertising, etc.

But the first of these uses elements of information violence in a hidden form. It is emphasized that the term "media violence" denotes, rather than the role of information in the commission of violence acts, but rather the instrumental purpose of the newest media (through films, TV programs, videos, computer games, etc.) in the production of violence, the specificity of the transformation of violence in information to society as a whole.

Despite this is also distinguishes such a form of media violence as "streaming violence" (that is, socio-cultural violence that is carried out in a latent form based on the presentation of an untrustworthy world picture by introducing misinformation and increasing information flows at the same time). A form of media violence is "fictional violence" as the production of images and symbols of violence by artistic means and their dissemination through media sphere. Unlike documentary recording of violence acts, which are broadcast in reports or specialized chronicles, fictional violence takes place in films, computer games, literature, etc. Recently, trolling as a form of information violence has become widespread. It often has an organized, targeted nature and is a tool for influencing political, economic or social processes. Trolling can be carried out by special organizations ("bots") and form public opinion on request (in relation to specific persons or events). A form of media violence is advertising violence, which is carried out through false advertising or glut of advertising space in the urban space.

Key words: Symbolic Production and Exchange, Everyday Life, Intellectual Practices, Contemporary Art, Urban Space, Visual Anthropology, Post-Industrial Society

\footnotetext{
${ }^{*} \mathrm{PhD}$ in Philosophy, Associate Professor

(Zhytomyr Ivan Franko State University, Zhytomyr, Ukraine)

vadmyks1@gmail.com

ORCID: 0000-0002-5593-0622
} 


\section{ІНФОРМАЦІЙНЕ НАСКМАЯ У СИМВОАІЧНОМУ ОБМІНІ ТА СУЧАСНА МЕДІА РЕАМЬНІСТЬ: МОДУСНИЙ ВИМІР}

\section{B. M. Carocap}

У статті проаналізовано інформаиійне насилля як складову соиіального насилля. У контексті визначення форм насилля, зокрема при класифікації його за суб'єтом $i$ спрямованістю (самоспрямоване, міжособистісне та колективне) акиентовано увагу, шо воно виражаеться у соиіально-політичній, соиіально-економічній та соиіально-культурній формах. Складовою його реалізаиї̈ є поширення надмірної чи неправдивої інформації. Це пояснюеться тим, шо його здійснення потребує створення соиіокультурного продукту, яким $\epsilon$ специрічно підібраний відеоряд новин, особливий порядок $i$ форма подачі иих новин (порушення в них приниипів об'єктивності, висвітлення позииій лише однієї сторін конфлікту, апелювання до примітивних бажань в телепередачах), агресивна реклама і $m$. $\partial$.

Але перші із них використовують елементи інформаиійного насилля у прихованій формі. Наголошено, шуо поняття "інформаційне насилля" позначає не роль інформації при здійсненні насильницьких актів, а інструментальне призначення новітніх засобів масової інформаціі (через фрільми, телепередачі, відеоролики, комп'ютерні ігри і т.д.) у продукуванні насилля, спеиифіку трансформаиії насилля в інформаиійному суспільстві загалом.

Крім того, виокремлено такий різновид інформаиійного насилля як "потокове насилля" (соиіально-культурне насилля, яке здійснюеться у латентній формі на основі репрезентації недостовірної картини світу через введення дезінформаиії $і$ збільшення обсягів інформаиіі водночас). Різновидом інформаційного насилля $\epsilon$ "фікиіональне насилля" як продукування художніми засобами образів та символів насилля $і$ поширення їх через медіа сфреру. На відміну від документального фіксування актів насилля, які транслюються у репортажах чи спеціалізованих хроніках, фрікиійне насилля має місие у художніх фрільмах, комп'ютерних іграх, літературі та ін. Останнім часом поширеним став тролінг як різновид інформаиійного насилля. Він часто має иілеспрямований характер іє інструментом впливу на соиіальні процеси. Тролінг може здійснюватися спеиіальними організаиіями ("ботофермами") і формувати громадську думку на замовлення (стосовно конкретних осіб чи подій). Різновидом інформаиійного насилля $є$ рекламне насилля, шоо здійснюється через неправдиву рекламу чи перенасичення рекламними поданнями міського простору.

Ключові слова: символічне виробниитво та обмін, повсякденність, інтелектуальні
пактики, сучасне мистеитво, урбанізований простір, візуальна антропологія, постіндустріальне суспільство

Introduction of the issue. Today's globalized world is marked by the qualitative change in forms and types of social violence, the assertion of media reality as a space for counteracting major conflicts and subjects of violence. The concept of "Global Village" by M. McLuhan, as a principle of contemporary media reality, reveals not only the new content of communication (but the social interaction which media becomes one of the leading instruments). They are now a significant element of the symbolic production and exchange of modern society. However, there is a tendency to blur the distinction between such phenomena as informational influence, media violence, manipulation and propaganda.

Their traditional identifiers, which identified the need to use appropriate fuses as implementing ethics and standards of professional ethics, in particular, journalistic ethics and PR ethics, into legislative documents, to develop state programs to counter bias, tendency propaganda by various social institutions or agents of influence, they work properly, especially in the countries of Eastern and Central Europe. In recent years, the phenomenon of media violence has become the main source which is $\mathrm{TV}$, the blogosphere, street advertising and advertising on transport, which is of 
concern to the average inhabitant of the modern city. But it is not yet explored in depth by specialists, including philosophers, estheticians, cultural scientists, urban specialists, and others. This determines the relevance of this study.

Current state of the issue. The problems of media violence are devoted to the works by C. Andersen, A. Vasylevich, O. Dzyoban, D. Methylka, V.Ostroukhov, O.Panfilov, V. Pylypchuk, C. Plante, A. Skoryk, S. Sobolyeva, and others. In particular, the collective monograph Informational Security of the State by V. Ostroukhov is analyzes media violence at both theoretical and empirical levels, describes the techniques of manipulative practices, and becomes a significant contribution in recent years. Dzyoban, Panfilov, and Sobolyeva attempted to define broadly and narrowly the meaning of "media violence".

D. North, J. Wallis, B. Weingast, in their social order studies, distinguish organized violence as violence, which is implemented by organized groups, essentially a particular form of collective violence and, to some extent, close to structural. The development of large groups in society leads to the formation of relevant social institutions, which main function is to control violence, they include formal rules, written laws, formal social agreements, informal norms of behavior, as well as beliefs about the world and means to compel these rules and regulations [20: 59]. Control of violence by formal institutions is only possible if there are appropriate organizations capable of enforcing impersonal rules.

The outline of unresolved issues brought up in the article. An analysis of recent research into the problem of media violence shows the growing scientific interest in this social phenomenon by scholars in various fields: philosophy, psychology, political science, journalism, pedagogy, etc. In the philosophical sciences, the problem of defining the concept of "media violence", the development of mechanisms for its depression, the analysis of the impact of media violence on the security of society and the state are actualized. In the interdisciplinary plane, tools for influencing the formation of a "culture of peace" that counteract media violence are being explored.

The purpose of the article is to determine the place and specificity of media violence as a form of violence in the symbolic production and exchange of modern society. The object of the study is information violence in its modes. As a working hypothesis, we argue that information violence is a component of cultural violence and is expressed in various forms. The main methods are phenomenological for analyzing information violence as a phenomenon of media reality and comparative for performing comparative analysis of various manifestations of media violence.

Results and discussion. Research on the problem of violence as a social phenomenon traditionally in the philosophical sciences has focused primarily on its political and economic forms. But at the beginning of the twentieth century, a completely different approach was adopted, based on a critique of violence that sought to identify "pure violence" in the balance of law, justice and violence. The work Reflections on Violence by Georges Sorel's, The Spirit of Utopia by E. Bloch's, Critique of Violence by Walter Benjamin's became fundamental to this trend [24: 19]. By considering the typology of forms of violence by subject and orientation, they distinguish between self-directed, interpersonal and collective violence; collective violence is expressed in sociopolitical, socio-economic and sociocultural forms [23: 132]. The identification of cultural violence as a separate form of social violence occurred in socio-humanities only in the nineties of the twentieth century, which is observed in the works by J. Butler, Z. Bauman, J. Galtung, W. Sofsky. 
Although one of the key aspects of the socio-cultural violence implementationsymbolic violence was talked about in the 1970s by P. Bourdieu and J. Passeron stated that the primary purpose of the symbolic violence power was to impose certain values and compulsions to be recognized as legitimate while the fundamental power relations are hidden [15: 22]. As you can see, even a pedagogical influence can impose a "cultural tyranny" on a young person. D. Boiko defines the following characteristics of symbolic violence: it implies "imposing values" and legitimizing them; implemented in a latent form, functions in the form of hidden "impositions of values", replacing real spheres of opposition with symbolic; partially replaces physical violence; is the purpose and means of symbolic capital; the symbolic violence is mainly the subject of the state, the symbolic violence being directly related to, but not limited to, the process of symbolic struggle [1: 59-60]. C. Andersen and C. Plante, while revealing the content of contemporary information violence, emphasize that, despite the large amount of his research, the problem of sufficient grounds to argue about the determinative impact of information violence on an individual's asocial behavior is actualized by scientists.

The role of symbolic violence in the processes of social transformation is not so much a change in the social world, but rather a change in the ways of its formation, above all its reflection and the practical operations through which groups are formed and reproduced. This is done under certain conditions: 1) possession of symbolic power, which forms new groups and structures; 2) symbolic capital (trust, recognition, authority); 3) relevant social demands or expectations, that is, the relevance of specific transformation processes for the society itself [14]. For example, the symbolic struggle to impose a definition of social peace involves different social groups, communities, classes. But the struggle is carried out either through symbolic conflicts in daily life by all individuals or "by agreement", in particular by specialists in symbolic production, whose aim is to establish a monopoly on legitimate symbolic violence [14: 92]. Thus, symbolic violence in this context is a phenomenon of the approval of specific projects of social transformation, which is carried out at the level of ideas, theories, etc.

At the beginning of the twentieth century, G. Sorel distinguished three forms of violence according to the level of its implementation. At the lowest violence is dispersed. it acts through the conditions of living, labor and production of material goods and manifests itself as tax measures. Above is violence as a concentrated power of the state, it is directed to work (regulation of wages, working hours). The highest is violence itself [11: 166-167]. The logical sequence of these forms manifests itself in the role and place of freedom in each of them: from the smallest manifestation to those in which it is realized in its own planned plans, that is, social transformations.

Norwegian researcher on violence J. Galtung proposed a typology of violence by nature of action, distinguishing three pairs: physical and internal; with and without object; direct threat or indirect; personal (direct) and structural (indirect); intentional and unintentional; the obvious and the latent [4: 169-172]. This typology has been further developed in scientific intelligence in the social sciences and humanities, but it has been substantially criticized. Attempts to find out the essence of violence, its social content and peculiarities of functioning in society in order to develop a theoretical basis of social relationships without violence allowed scientists to distinguish the following forms of violence, depending on the presence of the subject of action (actor) and according to his character of 
social manifestation: physical, structural, systemic.

Yes, physical violence is direct action violence, that is, it is committed by specific individuals, and for a structural and systemic individual, functionally, it is rather an instrument of violence than its subject. In a period of progressive development, physical violence forms appropriate boundary barriers to the alternative of its avoidance which inherently constitutes power [7]. The use of force as well as violence is governed solely by the legal system of society and is predominantly demonstrative in nature, which requires individuals to become aware of the power in government that provokes it to cause physical violence. Developing mechanisms of suppression or newest elimination of the latter leads to the emergence of violence forms using of which requires the subject of rational explanation of the object or objects of its need. In this way, physical violence acts as a way of avoiding events because the consequences of its use are "neglected" in the historical memory of society.

Therefore, the transfer of such images (mediator) is a media capable of disseminating them in various modifications, which implies total coverage of all social communities and groups.

Structural violence is defined as the "silent" violence of social inequality and injustice which similarly destroys people's lives or threatens them, but not by direct action, attacks, but by inevitable poverty, famine, epidemics, etc. or extreme disenfranchisement [8: 18]. It should be emphasized that the concept of "structural violence" was introduced by J. Galtung in the work Violence, Peace and the Search for Peace. Violence, according to Galtung, is built into structure and manifests itself as unequal power and, accordingly, as unequal life opportunities [4: 171]. Therefore, the uneven allocation of resources in terms of income, education, and medical services leads to uneven distribution of power. D. Sengha focuses on social organization as the source of this form of violence. He notes that "we always speak of structural violence when a society is organized in such a way that its principles of organization of social order and existence are social injustice, unequal life chances and sharp differences in positions of power and thus in the possibilities of influence" [10: 117]. An important characteristic of violence by repressive structures is the support, coherence of people's actions, including those to whom it is directed.

Systemic violence is interpreted by S. Zizek as system-specific violence, direct and indirect forms of violence (including threats of violence) that support relations of domination and exploitation. In the social context of global capitalism, the realization of systemic violence also implies the "automatic" creation of excluded and "extra" people (from homeless to unemployed) [18: 15-16]. D. Becker proposed the concept of "Systemic Violence" to denote the relationship between the use of violence in society and it's processing by the media [13: 69]. It is primarily about the function of attributing (stigmatizing) actions to violence about the separation of the active and intentional components of violence. Enrollment into violence causes an asymmetry between the subject and the object, which is simplified in the communication system.

But in social systems, violence is used to reduce communication to action which leads to the statement of the impossibility of overcoming it. In systems in which communication is based on experiences, not actions (in particular, in religion, science, art), communication loses its violent character [13]. Thus, systemic violence, through the function of stigma, counteracts transformation processes.

$T$. Shipunova defines the following principles on which systematic violence is carried out through the technique of 
maintaining domination: legitimation of certain norms, which make it possible to participate directly in public life; determination of the fact of norms violation as a result of "Moral Guilt" of the offender; state controlling organizations that carry out the functions of punishment [25: 314]. This allows to pay attention to the relevant social institutions that exercise social control on the basis of a system of "Social Order" developed and approved by law, and through a system of intimidation mechanisms that include the risk the danger of the death penalty being applied to violators, imprisonment, physical and mental punishment, the threat of "social death". Some scholars, including Peter Imbush and Peter Waldman, have singled out institutional violence which is defined as the sanctioned power of authority given to those who hold hierarchical positions of subjugation and dependence [12: 431]. It has many varieties, depending on what it takes and what organizations implement it. However, to my mind, institutional violence is more structural in its content, though it contains systemic features. As for me, media violence, although inherently present in socio-political and socio-economic violence, is a kind of cultural one that contains elements of structural and systemic forms. This is explained by the fact that its implementation requires the production of a socio-cultural product which is a "properly" selected video series of news, the procedure and form of presenting these news, violations of the principles of objectivity, coverage of positions of the parties to the conflict, appeal to terrestrial instincts in television programs, various types of aggression etc. But the first of these types use elements of information violence without defining their content.

Let us say that cultural aspects can be considered as separate aspects of communication culture and everyday culture. They can be used to justify and legitimize outright illegitimate institutional or structural violence, that is, its primary purpose is to present other forms of violence as legitimate for society to recognize as acceptable [5: 341]. Bullying is socio-culturally encoded, in other words, it has "levers of influence" based on the cultural heritage of a particular society. However, forms of socio-cultural coding are not included in the intentionality, they simultaneously possess elements of ritual, expression, performativity; violence becomes real in the symbolically mediated fabric of signs, meanings, ceremonies and performances, it becomes meaningful, communicated and transported through the media [6: 315]. Socio-cultural violence is aimed at switching in the mass consciousness the moral assessment of a particular activity or action from "wrong" to "correct", to obscure the public perception of activity or violence facts. In the process of social transformation, violence which seeks to destroy certain social norms and rules, receives resistance from the society, but thanks to the action of the cultural form, it is stigmatized as a "necessary one-time action" and is perceived as a slight excess of power.

Nowadays, the concept of "media violence" is only affirmed in scientific discourse. This is compounded by the fact that most scholars focus on the role of information in the process of violence. But the obvious fact is that in the simplest forms and forms of violence, information is always present, since violence is not only and not so much an act of using force as it is a threat to use it. For the most part, the purpose of social violence is to force its object to abandon certain actions because of the threat of its own existence, or because of the high resource-consuming counteraction. (Exactly such information is transmitted to the opponent even if it is physical violence).

Another aspect of the current debate about giving media violence status as a social phenomenon is the lack of 
evidence at the experimental level of the destructive impact of mass-produced violence, that is, films, TV shows, and video games that contain scenes of violence determine the aggressive person. But, as C. Andersen and C. Plante point out, "The fact that, among American teenagers, $97 \%$ play video games and the average time per day spent in front of some form of media is about 7,5 hours means that these small effects can have a significant impact when applied on a societal scale and, as such, can have important implications for social policy" [9: 9]. We argue that the notion of "media violence" denotes, rather than the role of information in the commission of violence acts, but rather the instrumental purpose of the latest media (through films, TV shows, videos, computer games, etc.) in the production of violence, the specificity of the violence transformation into the informational society as a whole. Instant dissemination to a wide audience of violence scenes, its symbols and images can provoke a reaction in the mass consciousness and cause appropriate social actions. For example, video footage of students being beaten on Maidan on November 30, 2013 provoked an immediate reaction from the population and a spontaneous organization of mass protest the next day. Another example is the media violence of street and transport advertisements which, as "garbage", shapes the image of the city, altering both the urbanized space of everyday life and its relation to the world.

However, such information (including misinformation and partial information) can become a tool of manipulation in the mass consciousness. Thus, information violence becomes a component of sociocultural violence that is produced by the mass media (including the latest) through symbolic exchange.

Then the symbolic exchange in the context of the problem of violence is realized through the "summary symbol" which appears as a concentrated consolidation of a holistic complex of social problems of destructive content, an abstraction of their relevance and peculiarities. The symbol, according to J. Eiserman, is "the definition of positional violence both to simplify the complex context of problems and to absorb social contradictions" [3:29]. In other words, symbolic exchange allows one to stigmatize violence as "undesirable" and, on the other, as necessary. At the same time, society is both producing and degrading violence.

Violence in the information society is indicated by its virtualization, displacement of direct violence by indirect; increasing its anonymity, transforming discrete acts of violence into continual ones, "defocusing", "blurring the boundaries" of violence; the technical improvement of the means of public consciousness manipulation, the emergence of new types of violence related to new communication technologies [19: 211]. Such Ukrainian researchers as O. Dzyoban, O. Panfilov, and S. Sobolyeva propose to consider the following aspects of this social phenomenon: 1) protection against information; 2) a component of terror; 3) an image of violence in television broadcasts; 4) a manipulation of consciousness; 5) the availability of information resources for the average user which more often contributes to its powdering, anesthesia, than activity; 6) such, the content of which is determined by the forms of control over the consequences of the influence of the media [17].

On this basis, we can distinguish such a form of media violence as "streaming violence", that is, sociocultural violence which is carried out in a latent form based on the representation of an untrustworthy world picture by introducing misinformation and increasing information flows at the same time. Here, the key problem of counteracting information violence, namely the 
formation of a culture of information verification, is relevant. The large amount of information that has traditionally been regarded as credible is now largely formed by non-specialists with the introduction of modern Internet technologies. Being accessible to everyone in news formation increases the share of unreliable information in these streams. Thus, in the media sphere, the practice of referring to posts on social networks has been established, and the increase in the share of such reposts in general eliminates the content of training of media specialists, as specialists who not only have the skills of technological design of news but also the skills of content work with information. Creating a universal encyclopedia such as Wikipedia has greatly simplified the process of finding encyclopedic content. But at the same time, despite the introduction of peer review of submitted materials, it also increased the likelihood of producing false information. Therefore, this also requires the formation of a culture of validation by other official sources in the users of the culture.

Another type of information violence is "fictional violence". It is the production of media images and symbols of violence by artistic means. That is, unlike documentary recording of acts of violence which are broadcast in reports and specialized chronicles, fictitious inherent in feature films, computer games, literature, etc. The depiction of violent scenes was often aimed at experiencing a sense of revulsion (for example, a provocative film by Pasolini's The Salom or 120 Days of Sodom). But now there is romanticizing of violence (at least a series of Rambo films). In recent decades, the genre of computer-based action games has emerged, in which the protagonist physically destroys opponents, and the scenes of violence are extremely detailed. Nowadays, many studies of fictional violence in the subject area of psychology, cultural studies and sociology are being carried out regarding the impact of fictional scenes of fictional violence on a person's behavior, regarding its implementation in practical life. This topic became especially relevant after the terrorist attack on a mosque in Christchurch, New Zealand which was broadcast online by an attacker [2]. This demonstrates, firstly, the likelihood of transposing physical violence into actual implementation, secondly, the lack of adequate socio-cultural mechanisms to prevent such transitions. It's meaningful to differentiate information violence based on factors of influence. Thus, according to the instrumental classification by V. Ostroukhov, it's possible to distinguish information violence carried out under the influence of physical and internal factors [21: 116138]. The first factor of the Ukrainian philosopher includes are sound (musical and binaural rhythm) and light (effects of light flashes, flickering and color) phenomena. Others include informationpsychological, psychotropic and others influences.

In recent years, such a form of information violence as trolling has emerged and is approved which first emerged as a form of discussion, often anonymously or by fictional figures. Nowadays, trolling often has an organized, directed nature and is a tool for influencing political, economic or social processes. It can be carried out by special organizations called "bot farm" and to form public opinion about specific individuals or events. The purpose of trolling is not the elemental infliction of internally personal or "information trauma" on the opponent, and he, as Adrian Skoryk points out, "becomes a very sophisticated and cruel means of "violence of the subject", destruction, humiliation, neglect of personality ... that is, today we can talk about a certain concept on the Internet and through trolling, the dissemination of "distorted information in media communication systems" [22: 334]. Trolling as a form of 
information violence becomes an instrument of information warfare.

An important area of contemporary media reality in which information violence is produced is advertising space. Of course, there is now a tendency to identify different types of advertising and to oppose advertising in post-industrial society. But O. Dzyoban and V. Pylypchuk emphasize: "Advertising is an inevitable evil of the present time, an evil because it disturbs and distorts the natural perception of information. It goes without saying that many of the victims of the advertising pressure were admitted that they did not buy what they needed, voted in the wrong way, and so on. At first, a completely constructive function of advertising - not to get lost in the market the remainder has changed dramatically over time. The tendency of manipulate in the mass consciousness is becoming increasingly apparent" [16: 7374]. To my mind, such "demonization" of advertising is not justified because it ignores the sphere of social advertising, whose influence is not stigmatized as violent. The task of any work of art is to influence the emotional behavior of a person, and experiencing the beautiful by it is also not violence.

However, it should be noted that the adoption of modern information technology, which significantly increased the forms and opportunities for advertising products, has led to the fact that the creation of an advertising product has become widespread. This led to a shortage of advertising space and its aggressive expansion, replacing it with socio-cultural aspect and everyday life. In this case, the main impact is primarily within the urban space. Information violence through advertising is done not so much through aggressive advertising, but rather as an increase in the volume of the visual advertising product and the saturation of human life space. Here, to my mind, we should emphasize the tendency of advertising amount increasing which causes the appearance of more aggressive advertising is a kind of information violence. But at present there is no factual basis for claiming its dominance over other types of advertising which will be a prospect for further research.

\section{Conclusions}

and

research

perspectives. Media violence is a type of socio-cultural violence that includes elements of structural and systemic plan forms. It's produced today by the mass media (including the newest ones) through the symbolic exchange of society.

The term "media violence" refers to the instrumental purpose of the latest media (through movies, TV shows, computer games, etc.) in producing scenes of violence. Varieties of information violence are streaming; fictional; violence committed under the influence of physical and internal factors; trolling, and violence in the advertising space.

\section{LITERATURA}

1. Boiko, D. (2016). Symbolic Violenceas the Object of Sociological Research: Inter Bourdieu and Zizek. Вісник Харківського національного університету імені В. $H$. Каразіна. № 36. С. 57-61.

2. Christchurch shootings: 49 dead in New Zealand mosque attacks (15 March 2019). Eresource. Access mode: https://www.bbc.com/ news/world-asia-47578798 (Last accessed: 20.06.2019).

3. Eisermann, J. (2001). Mediengewalt. Die gesellt schafliche Kontrolle von Gewaltdarstellungen im Fernsehen. Wiesbaden: Westdeutscher Verlag GmbH.

4. Galtung, J. (1969). Violence, Peace, and Peace Research. Journal of Peace Research. Vol. 6, No. 3. 167-191.

5. Galtung, J. (1998). Friedenmitfriedlichen Mitteln: Friede und Konflikt, Entwicklung und Kultur. Opladen: Leske + Budrich.

6. Jaeger F. (2005). Der Mensch und die Gewalt. Perspektiven der historischen Forschung In Jürgen Straub (Hg.). Wasistder Mensch, was Geschichte? Annäherunge naneine kultur wissenschaftliche Anthropologie. Bielefeld: Transcript.

7. Luhmann N. (2012). Macht. Stuttgart: UTB GmbH.

8. Nolting H.-P. (2004) Psychologie politischer Gewalt: drei Ebenen In Gert Sommer, 
Albert Fuchs (Hrsg.) Krieg und Frieden. Handbuch der Konflikt- und Friedenspsychologie (S. 18 - 30). Weinheim, Basel, Berlin: Beltz Verlag.

9. Plante C.N. \& Anderson C.A. (2017). Media, Violence, Aggression, and Antisocial Behavior: Is the Link Causal? In Sturmey P. The Wiley Handbook of Violence and Aggression. New Jersey: Wiley-Blackwell.

10. Senghaas D. (1974). Gewalt- KonfliktFrieden. Essayszur Friedensforschung. Hamburg: Hoffmann\& Campe Verlag.

11. Sorel G. (2004). Reflectionson Violence (edited by Jeremy Jennings). Cambridge: CambridgeUniversityPress.

12. Waldmann P. (1992). Politikund Gewalt. In Dieter Nohlen (herausgegeben) Lexikon der Politik. Gesamtwerk, Bd. 1-7. (Band I Politische Theorien. München: Verlag C. H. Beck. S. 430 435.

13. Бекер Д. (1994). Понятие системного насилия // Проблемы теоретической соииологии Санкт-Петербург: Петрополис. C. $55-72$.

14. Бурдье П. (2007). О символической власти // Бурдье П. Соииология соииального пространства. Москва: Институт экспериментальной социологии. СанктПетербург: Алетейя. С. 87-96.

15. Бурдье П. Пассрон Ж.-К. (2007). Воспроизводство: элементы теориисистемы образования. Москва: Просвещение.

16. Дзьобань О. П., Пилипчук В. Г. (2011). Інформаиійне насильство та безпека: світоглядно-правові аспекти : монографія. Харків, 244.

17. Дзьобань О. П., Панфілов О.Ю., Соболєва С. М. (2016). Інформаційне насильство: змістовний аспект. Вісник Наиіонального університету "Юридична академія України імені Ярослава Мудрого". Серія: Філософрiя. № 1. 136 -151.

18. Жижек С. (2010). О насилии. Москва: Европа.

19. Метілка Д. В. (2009). Насимяя в інформаційному суспільстві. Гілея. Bun. 209, $209-215$.

20. Норт Д., Уомиис Дж., Вайнгаст Б. (2011). Насилие u соииальные порядки. Кониептуальные ралки для интерпретаиии письменной истории человечества. Москва: Изд. Института Гайдара.

21. Остроухов В. В. (заг. ред.). (2016). Інформаиійна безпека держави. Київ: Книжкова палата України.
22. Скорик А. (2014). Насимяя і суб'єкт в сучасній аудіовізуальній культурі. Музичне мистеитво і культура, 20. С. 327 - 337.

23. Слюсар В. М. (2016). Соціальне насимяя: зміст і форми реалізації у трансформаційних процесах. Вісник Житомирсъкого державного університету імені Івана Франка. Bun. 1 (82). Сер. "Фі^ософські науки". С. 127 - 132.

24. Слюсар В. М. (2017). Насилля: соиіально-філософська природа [монографія]. Житомир: Вид. Євенок О. О.

25. Шипунова Т. В. (2010). Системное насилие в контексте социального контроля девиантности. Российский криминологический взгляд. № 3. С. 313 320.

\section{REFERENCES (TRANSLATED \& TRANSLITERATED)}

1. Boiko, D. Symbolic Violence as the Object of Sociological Research: Inter Bourdieu and Zizek. Visnyk Kharkivskoho natsionalnoho universytetu imeni V. N. Karazina, 2016, № 36, 57-61.

2. Christchurchshootings: 49 deadin New Zealand mosqueattacks (15 March 2019). Eresource. Access mode: https://www.bbc.com/news/world-asia-

47578798 (Last accessed: 20.06.2019).

3. Eisermann, J. (2001). Mediengewalt. Die gesellschafliche Kontrolle von Gewaltdarstellungen im Fernsehen. [Mediaviolence. The social control of violence on television]. Wiesbaden: Westdeutscher Verlag $\mathrm{GmbH}$ (in Germany).

4. Galtung, J. Violence, Peace, and Peace Research. Journal of Peace Research, 1969, Vol. 6, No. 3, 167-191.

5. Galtung, J. (1998). Friedenmitfriedlichen Mitteln: Friede und Konflikt, Entwicklung und Kultur [Peace through peace fulmeans: peace and conflict, development and culture]. Opladen: Leske + Budrich (in Germany).

6. Jaeger, F. (2005). Der Mensch und die Gewalt. Perspektiven der historischen Forschung [Man and violence. Perspectives of historical research] In Jürgen Straub (Hg.). Wasist der Mensch, was Geschichte? Annäherungenaneine kultur wissens chaftliche Anthropologie [Whatisman, whatishistory? Approaches to a cultural anthropology]. Bielefeld: Transcript (in Germany).

7. Luhmann, N. (2012). Macht [Power]. Stuttgart: UTB GmbH (in Germany). 
8. Nolting, H.-P. (2004) Psychologie politischer Gewalt: drei Ebenen [Psychology of political violence: threelevels]. In Gert Sommer, Albert Fuchs (Hrsg.) Krieg und Frieden. Handbuch der Konflikt- und Friedenspsychologie [Warandpeace. Handbook of Conflictand Peace Psychology]. Weinheim, Basel, Berlin: Beltz Verlag, 18-30 (in Germany).

9. Plante, C.N., Anderson, C.A. (2017). Media, Violence, Aggression, and Antisocial Behavior: Is the Link Causal? in Sturmey P. The Wiley Handbook of Violence and Aggression. New Jersey: Wiley-Blackwell.

10. Senghaas, D. (1974). Gewalt-KonfliktFrieden. Essayszur Friedensforschung [Violence Conflict - Peace. Essayson peace research]. Hamburg: Hoffmann\&Campe Verlag (in Germany).

11. Sorel, G. (2004). Reflectionson Violence (edited by Jeremy Jennings). Cambridge: Cambridge University Press.

12. Waldmann, P. (1992). Politik und Gewalt [Politics and violence]. In Dieter Nohlen (herausgegeben) Lexikon der Politik. Gesamtwerk [Dictionary of Politics. Completeworks], Bd. 1-7. (Band I Politische Theorien München: Verlag C. H. Beck, 430-435) (in Germany).

13. Beker, D. (1994). Ponyatie sistemnogo nasiliya [The concept of systemic violence]. V Problemy teoreticheskoj sociologii. SanktPeterburg: "Petropolis", 55-72 (in Russian).

14. Burde, P. (2007). O simvolicheskoj vlasti [On the symbolic power]. V Burde P. Sociologiya socialnogo prostranstua. Moskva: Institut eksperimentalnoj sociologii ; Sankt Peterburg: Aletejya, 87-96 (in Russian).

15. Burde, P. Passron, Zh.-K. (2007). Vosproizvodstuo: elementy teorii sistemy obrazovaniya [Reproduction: Elements of the Theory of Education System. On Symbolic Power]. Moskva: Prosveshenie (in Russian).

16. Dzoban, O. P., Pylypchuk, V. H. (2011). Informatsiine nasylstuo ta bezpeka: svitohliadnopravovi aspekty : monohrafiia [Media violence and security: legal aspects: a monograph]. Kharkiv (in Ukrainian).

17. Dzoban, O. P., Panfilov, O. \& Sobolieva, S. M. Informatsiine nasylstvo: zmistovnyi aspekt [Mediaviolence: a meaningful aspect]. Visnyk
Natsionalnoho universytetu "Iurydychna akademiia Ukrainy imeni Yaroslava Mudroho". Seriia: Filosofiia, 2016, № 1, 136-151 (in Ukrainian).

18. Zhizhek, S. (2010). O nasilii [About violence]. Moskva: Evropa (in Russian).

19. Metilka, D. V. Nasyllia v informatsiinomu suspilstvi /Violence in the Information Society]. Hileia, 2009, Vyp. 209, 209215 (in Ukrainian).

20. Nort, D. Uollis, Dzh., Vajngast, B. (2011). Nasilie $i$ socialnye poryadki. Konceptualnye ramki dlya interpretacii pismennoj istorii chelovechestua [Violence and Social Orders: A Conceptual Framework for Interpreting Recorded Human History]. Moskva: Izd. Instituta Gajdara (in Russian).

21. Ostroukhov, V. V. (zah. red.). (2016). Informatsiina bezpeka derzhavy [Information security of the state]. Kyiv. DNU "Knyzhkova palata Ukrainy" (in Ukrainian).

22. Skoryk, A. Nasyllia i subiekt v suchasnii audiovizualnii kulturi [Violence and subjectin to day's audio visual culture]. Muzychnemystetstvo $i$ kultura. 2014, 20, 327-337 (in Ukrainian).

23. Slyusar, V. M. Sotsialnenasyllia: zmist i formyrealizatsii $u$ transformatsiinykh protsesakh [Social Violence: The Content and Forms of Implementationin Transformational Processes]. Visnyk Zhytomyrskoho derzhavnoho universytetu imeni Ivana Franka. 2016, Vyp. 1 (82) "Filosofskinauky", 127-132 (in Ukrainian).

24. Slyusar, V. M. (2017) Nasyllia: sotsialnofilosofska pryroda /Violence: socio-philosophical nature [monograph]. Zhytomyr: Vyd. Yevenok O.O. (in Ukrainian).

25. Shipunova, T. V. Sistemnoe nasilie v kontekste socialnogo kontrolya deviantnosti [Systemic violence in the context of social control of deviance]. Rossijskij kriminologicheskij vzglyad. (2010, № 3, 313-320 (in Russian).

Receive: June 25, 2019 Accepted: September 14, 2019 